\title{
Availability and accumulation of lead for forage grasses in contaminated soil
}

\author{
S. S. Nascimento ${ }^{1}$, E. B. Silva ${ }^{1 *}$, L. R. F. Alleoni ${ }^{2}$, P. H. Grazziotti ${ }^{3}$, F. G. Fonseca ${ }^{1}$; B. O. Nardis ${ }^{1}$ \\ ${ }^{1}$ Department of Agronomy, UFVJM, Campus JK, Rodovia MGT 367, 5000, Diamantina, Minas Gerais, 39100- \\ 000, Brazil. *Corresponding author: ebsilva@ufvjm.edu.br \\ ${ }^{2}$ Department of Soil Science, ESALQ, University of São Paulo, Av. Pádua Dias, 11, Piracicaba, São Paulo, \\ 13418-900, Brazil. \\ ${ }^{3}$ Department of Forestry, UFVJM, Campus JK, Rodovia MGT 367, 5000, Diamantina, Minas Gerais, 39100- \\ 000, Brazil.
}

\begin{abstract}
The forage grasses are explored for the phytoremediation of heavy metals from contaminated areas. The present study evaluates the tolerance of forages grasses to $\mathrm{Pb}$ and the availability of $\mathrm{Pb}$ for the Mehlich 1, DTPA, and USEPA 3051 and 3052 extraction methods. The forage grasses cultivars Panicum maximum cultivars Aruana and Tanzânia, Brachiaria decumbens cultivar Basilisk, Brachiaria brizantha cultivar Xaraés and Marandu were assessed. Each cultivar was grown in a greenhouse in Diamantina, Brazil, in Typic Hapludox (Oxisol). The $\mathrm{Pb}$ was applied to the soil at doses of $0,45,90$ and $270 \mathrm{mg} \mathrm{kg}^{-1}$ soil in a randomized design with four replications. The experiment was conducted over a 90-day trial period. Increasing $\mathrm{Pb}$ doses in the soil caused a reduction of growth in all varieties studied, and the "Basilisk" forage was generally more tolerant to $\mathrm{Pb}$, while the Xaraés forage was generally more susceptible to the addition of $\mathrm{Pb}$. The lower transfer coefficient of the cultivar "Basilisk", due to the high $\mathrm{Pb}$ content and accumulation in its roots, makes it the most suitable for phytoremediation programs, with possible uses in pasture areas. None of the varieties can be considered a $\mathrm{Pb}$ hyperaccumulator. The Mehlich 1, DTPA, USEPA 3051 and USEPA 3052 extraction methods indicated different doses of $\mathrm{Pb}$ in the soil, and the Mehlich 1 method demonstrated the lowest level of metal extraction from the soil. No correlation was observed between the forage grasses growth and the measurement of $\mathrm{Pb}$ in soil by the studied extraction methods, especially for the Mehlich 1 and DTPA methods, suggesting the inefficiency of these techniques for determining the phytoavailability of $\mathrm{Pb}$.
\end{abstract}

Keywords: Degraded areas, extractors, phytoremediation, Panicum sp., Brachiaria sp. 


\section{Introduction}

The intensification of industrial, agricultural and urbanization activities has increased the risk of soil pollution by potentially toxic elements. Soil pollution can have serious consequences for ecosystems because, through the absorption of these elements by plants, heavy metals can enter the food chain, contaminating both animals and humans (Wuana and Okieimen, 2011). Great efforts have been made to develop strategies for the remediation of this pollution using plants that can detoxify or decontaminate the soil.

The availability of heavy metals to plants is influenced by the following soil properties: $\mathrm{pH}$; redox potential; texture; mineral composition (as determined by content); and the types of clays and oxides of $\mathrm{Fe}, \mathrm{Al}$ and $\mathrm{Mn}$; soil profile characteristics; cation-exchange capacity (CEC); organic matter; the presence of other heavy metals; and other factors that affect microbial activity (Violante et al., 2010). The $\mathrm{Pb}$ in soil may be associated with: a) organic matter; b) clay minerals; c) oxides and hydroxides of $\mathrm{Mn}, \mathrm{Fe}$ and $\mathrm{Al}$; and may be easily dissolved in acidic environments (Kabata-Pendias and Pendias, 2001). The elevation of $\mathrm{pH}$ promotes the formation of $\mathrm{Pb}$ precipitates as hydroxides, phosphates and carbonates, as well as insoluble complexes with organic matter. Organic material associated with the elevation of $\mathrm{pH}$ slows the absorption of $\mathrm{Pb}$ by plants, as the $\mathrm{Pb}^{2+}$ ion forms complexes with humic compounds of the soil and becomes less available (Kabata-Pendias and Pendias, 2001; Wuana and Okieimen, 2011). Pb still has low mobility in soil due to its different interactions with the environment. Therefore, the addition of a chelating agent to increase the bioavailability of $\mathrm{Pb}$ is recommended in phytoremediation programs (Butcher, 2009). Phytoremediation involves the use of plants and their associated microbiota and amenizantes soil, along with proper agronomic practices (lime, fertilizer, organic matter etc.) to remove, immobilize or render contaminants harmless to the ecosystem (Wuana and Okieimen, 2011). Of great importance are the interactions that occur in the soil adjacent to the roots (rhizosphere). Plant roots exude a wide variety of organic compounds which support the microbial community and can facilitate the absorption of some metals (Zang et al., 2013). Phytoremediation is a highly site-specific technology, as it is dependent on the complex interactions between roots, microorganisms, metals and soils, and care must be taken to ensure that the technique is effective. Excess $\mathrm{Pb}$ can cause various symptoms of toxicity in plant species, including stunted growth, chlorosis, darkening of the root system, inhibition of photosynthesis, alterations in mineral nutrition and water balance, modification of hormonal status, and changes in the structure and permeability of the membrane (Sharma and Dubey, 2005). However, these effects are dependent on the species, variety and age of particular plants, along with the metal concentrations and the duration of their toxic effects (Akinci et al., 2010).

To predict the bioavailability of heavy metals in the soil, various methods of extraction have been tested, and the success of monitoring heavy metals in the soil depends partly on the chemical method used to measure the fraction of these elements effectively available to plants 
(Zhang et al., 2010). The various extraction methods can be classified, in general, into those using saline solutions, acid solutions, complexing solutions or combined solutions. In Brazil, there is no standard procedure to assess the availability of potentially toxic heavy metals such as $\mathrm{Ni}$ and $\mathrm{Pb}$. The analysis of heavy metal content in soils can be performed by determining the total content of the element in the soil, the exchangeable fraction and the soluble fraction. The total content of the element provides a measure of its prevalence in the soil, while the exchangeable fraction is a more direct measure of the probability of any detrimental effects to the environment (Zhang et al., 2010; Wuana and Okieimen, 2011).

Solutions of the chelating agent DTPA; acid solutions as Mehlich 1 or Mehlich 3; mixtures of acids; salts; and chelating agents have been used in several studies to extract heavy metals (Zhang et al., 2010). These extractors were developed for the evaluation of soil fertility, which facilitated the analysis of toxic elements, as these procedures are already in routine use at many laboratories. To monitor the contamination by heavy metals in soils, the Environmental Protection Agency of the United States recommends the determination of the total content in the sample (USEPA, 1997). Conventionally, this analysis requires digestion with hydrofluoric acid (HF) together with other strong acids. However, the use of HF in routine laboratories is not recommended because this reagent is difficult to handle (Hseu, 2004). For this reason, the use of $\mathrm{HNO}_{3}$ alone or in mixture with other acids, such as perchloric acid $\left(\mathrm{HNO}_{3}\right.$ $+\mathrm{HClO}_{4}-5: 1$ ) or $\mathrm{HCl}$ (aqua regia, $\mathrm{HCl}+\mathrm{HNO}_{3}$ - 3:1), is very common (Chen and Ma, 2001).
The USEPA method 3052 allows for the complete dissolution of metals from the sample, while the USEPA method 3051 achieves only partial dissolution of the metals present (semitotal). However, the results observed with the use of different extractors show considerable variation. Thus, it is a significant challenge to find an extractor capable of measuring the content of a potentially toxic element in a way which correlates with the content absorbed by plants. In this context, the objective of the present research was to evaluate the tolerance of forage grasses to $\mathrm{Pb}$ and to determine its availability in the soil using the Mehlich 1, DTPA, and USEPA 3051 and 3052 extraction methods.

\section{Material and Methods}

\subsection{Soil characterization and experimental design}

The experiment was conducted in the greenhouse in Diamantina (MG) $\left(18^{\circ} 14^{\prime} \mathrm{S}, 43^{\circ} 36^{\circ} \mathrm{W}, 1.250\right.$ $\mathrm{m}$ a.s.1.) in Brazil. The soil was a Typic Hapludox (Oxisol), due to be a soil with representative characteristics for livestock in Central Brazil, collected in the top layer of $0.20-0.40 \mathrm{~m}$, in Diamantina, Minas Gerais, Brazil.

Soil samples were air-dried, sieved $(2.0 \mathrm{~mm})$ and characterized according to Embrapa (1997) (Table 1). The $\mathrm{pH}$ was measured potentiometrically (soil: water 1:2.5, v/v); P and $\mathrm{K}$ were extracted by Mehlich-1 and determined by colorimetry $(\mathrm{P})$ and flame photometry $(\mathrm{K})$; $\mathrm{Ca}, \mathrm{Mg}$ and $\mathrm{Al}$ were extracted by $1 \mathrm{~mol} \mathrm{~L}^{-1} \mathrm{KCl}$ and determined by flame atomic absorption spectrophotometry ( $\mathrm{Ca}$ and $\mathrm{Mg}$ ) and titration with $0.025 \mathrm{~mol} \mathrm{~L}^{-1} \mathrm{NaOH}(\mathrm{Al})$; acidity $(\mathrm{H}+$ 
Al) was extracted with $0.5 \mathrm{~mol} \mathrm{~L}^{-1}$ calcium acetate buffered at $\mathrm{pH} 7.0$ and quantified by titration with $0.025 \mathrm{~mol} \mathrm{~L}^{-1} \mathrm{NaOH}$. The organic carbon (OC) was determined by Walkley-Black method. Values of $\mathrm{Al}$ and base saturation were calculated using the following equations: Al saturation $(\mathrm{m} \%)=(\mathrm{Al}) /\left(\sum \mathrm{K}, \mathrm{Ca}, \mathrm{Mg}, \mathrm{Al}\right) \times 100$ and base saturation $(\mathrm{V} \%)=(\mathrm{Ca}, \mathrm{Mg}, \mathrm{K}) /(\mathrm{CEC}) \times$ 100 . The values of $\mathrm{K}, \mathrm{Ca}, \mathrm{Mg}, \mathrm{H}+\mathrm{Al}$, and cation exchange capacity $\left(\mathrm{CEC}=\sum \mathrm{K}, \mathrm{Ca}, \mathrm{Mg}, \mathrm{H}+\right.$ $\mathrm{Al}$ ) are in $\mathrm{mmol}_{\mathrm{c}} \mathrm{kg}^{-1}$. Soil physical fractionation was performed using the densimeter method.

Table 1. Chemical and textural characterization before applying treatments

\begin{tabular}{lll}
\hline Property & Unit & Value \\
\hline $\mathrm{pH}^{\mathrm{a}}{ }_{\text {water }}$ & - & 4.9 \\
$\mathrm{P}^{\mathrm{b}}$ & $\mathrm{mg} \mathrm{kg}^{-1}$ & 0.4 \\
$\mathrm{~K}^{\mathrm{b}}$ & $\mathrm{mmol}_{\mathrm{c}} \mathrm{kg}^{-1}$ & 0.1 \\
$\mathrm{Ca}^{\mathrm{c}}$ & $\mathrm{mmol}_{\mathrm{c}} \mathrm{kg}^{-1}$ & 7.0 \\
$\mathrm{Mg}^{\mathrm{c}}$ & $\mathrm{mmol}_{\mathrm{c}} \mathrm{kg}^{-1}$ & 1.0 \\
$\mathrm{Al}^{\mathrm{c}}$ & $\mathrm{mmol}_{\mathrm{c}} \mathrm{kg}^{-1}$ & 1.0 \\
$\mathrm{CEC}^{\mathrm{d}}$ & $\mathrm{mmol}_{\mathrm{c}} \mathrm{kg}^{-1}$ & 81.0 \\
Organic carbon & $\mathrm{g} \mathrm{kg}^{-1}$ & 2.3 \\
$\mathrm{~Pb}, \mathrm{c}, \mathrm{f}, \mathrm{g}$ & $\mathrm{mg} \mathrm{kg}^{-1}$ & 0.0 \\
Sand & $\mathrm{g} \mathrm{kg}^{-1}$ & 730 \\
Loam & $\mathrm{g} \mathrm{kg}^{-1}$ & 70 \\
Clay & $\mathrm{g} \mathrm{kg}^{-1}$ & 200 \\
\hline
\end{tabular}

${ }^{\mathrm{a}}$ Soil:water 1:2.5; ${ }^{\mathrm{b}} \mathrm{Mehlich} 1$ extractor; ${ }^{\mathrm{c}} \mathrm{KCl} 1 \mathrm{~mol} \mathrm{~L}-1$ extractor; ${ }^{\mathrm{d}}$ Cation-exchange capacity; ${ }^{\mathrm{e} D T P A} ;{ }^{\mathrm{f}} \mathrm{USEPA}$ 3051; ${ }^{\mathrm{g} U S E P A} 3052$.

The initial $\mathrm{Pb}$ content of the soil was determined using the extractants Mehlich 1 (Embrapa, 1997) and diethylene-triaminepentaacetic acid - DTPA (Zhang et al., 2010). The semitotal Pb content in soil was defined using the USEPA 3051 method, with digestion in a microwave oven with concentrated $\mathrm{HNO}_{3}(65 \%)$ of analytical purity (USEPA, 2007), and total $\mathrm{Pb}$ content in the soil was determined using the USEPA 3052 method, with digestion in a microwave oven with $\mathrm{H}_{2} \mathrm{O}_{2}+\mathrm{HNO}_{3}+\mathrm{HF}$ and the addition of $\mathrm{H}_{3} \mathrm{BO}_{3}$ (USEPA, 2007) (Table 1).

Liming was conducted to raise the base saturation of the soil to $45 \%$. Lime requirement (LR) was calculated as $\operatorname{LR}\left(\mathrm{t} \mathrm{ha}^{-1}\right)=\left(\mathrm{V}_{2}-\mathrm{V}_{1}\right) \mathrm{CEC} / 100$, where $\mathrm{V}_{2}$ is the established base saturation $(45 \%)$ and $V_{1}$ is the current base saturation (soil analysis).

The soil was incubated for 30 days under moisture equivalent to $60 \%$ of the total pore volume (TPV) controlled by daily weighing. The basic fertilization of the planting was conducted as recommended in the vase experiment. Nutrients were applied as pure reagents and were mixed completely into the soil. The fertilizer doses consisted of $180 \mathrm{mg} \mathrm{N}$ (Urea, $\mathrm{NH}_{4} \mathrm{H}_{2} \mathrm{PO}_{4}$, $\left.\left(\mathrm{NH}_{4}\right)_{2} \mathrm{SO}_{4}, \mathrm{~Pb}\left(\mathrm{NO}_{3}\right)_{2}\right) ; 200 \mathrm{mg} \mathrm{P}\left(\mathrm{NH}_{4} \mathrm{H}_{2} \mathrm{PO}_{4}\right)$; $150 \mathrm{mg} \mathrm{K}(\mathrm{KCl}) ; 50 \mathrm{mg} \mathrm{S}\left(\left(\mathrm{NH}_{4}\right)_{2} \mathrm{SO}_{4}\right) ; 1 \mathrm{mg}$ $\mathrm{B}\left(\mathrm{H}_{3} \mathrm{BO}_{3}\right), 1.5 \mathrm{mg} \mathrm{Cu}\left(\mathrm{CuCl}_{2}\right), 5.0 \mathrm{mg} \mathrm{Fe}$ $\left(\mathrm{FeSO}_{4} \cdot 7 \mathrm{H}_{2} \mathrm{O}-\mathrm{EDTA}\right), 4.0 \mathrm{mg} \mathrm{Mn}\left(\mathrm{MnCl}_{2}\right.$. 
$\left.\mathrm{H}_{2} \mathrm{O}\right)$ and $4 \mathrm{mg} \mathrm{Zn}\left(\mathrm{ZnCl}_{2}\right)$ per $\mathrm{kg}$ soil, and the fertilizers were incubated for 15 days.

A completely randomized design was employed in this study, with four replications for each forage variety. Five grasses were evaluated: Brachiaria decumbens cultivar Basilisk, Brachiaria brizantha cultivars Xaraés and Marandu, Panicum maximum cultivars Tanzania and Aruana; four concentrations of $\mathrm{Pb}$ were applied in the form of pure lead nitrate: $0,45,90$ and $270 \mathrm{mg} \mathrm{kg}^{-1}$ soil. These $\mathrm{Pb}$ doses were based on the guidelines for use and occupation of the soil as indicated for the State of São Paulo, Brazil (São Paulo State Environmental Agency, 2005). The heavy metal was applied after the liming and fertilization, and the soil was incubated for 15 days under moisture equivalent to $60 \%$ of TPV, controlled by daily weighing.

The planting of the grasses was conducted by direct sowing in plastic pots containing $4 \mathrm{~kg}$ soil. Soil moisture was maintained at approximately $60 \%$ of the TPV by daily weighing and supplementing with deionized water to achieve the desired weight. After germination, the plants were thinned to one plant per pot. Thirty days after thinning, all plants were cut to a uniform height of $0.03 \mathrm{~m}$ from the stem base of each plant, initiating the evaluation period.

Plants were harvested every 30 days after the initial cutting. The first $\left(1^{\text {st }}\right)$ cut evaluation was made 30 days after the initial cutting, the second $\left(2^{\text {nd }}\right)$ cut occurred 30 days after the first cut, and the third $\left(3^{\text {rd }}\right)$ cut took place 30 days after the second cut. Fertilization with $30 \mathrm{mg} \mathrm{N}$ (urea) per kg of soil was conducted four times, once every five days after the uniformity cut in the first period of growth, and five times, with $60 \mathrm{mg} \mathrm{N}$ (urea) per $\mathrm{kg}$ of soil, once every five days during the last two periods.

\subsection{Sampling and analytical determinations}

After the final shoot cutting, 90 days after the initial cutting, the rest of the plant was collected: the stem base (connecting the roots to the shoots) and the roots. All of the collected plant material was washed in the following order: tap water, distilled water, diluted detergent, distilled water again, $0.1 \mathrm{~mol} \mathrm{~L}^{-1} \mathrm{HCl}$ solution, and a final wash of deionized water to remove any excess metal in superficial contact with the plant. Subsequently, the material was packed in paper bags and dried in an oven with forced air circulation at $65^{\circ} \mathrm{C}$ for 72 hours. After drying, the material was weighed on an analytical balance, and the dry weight of shoots (DWS) (the sum of the dry weight of the three cuts), the stem base (DWSB) and the roots (DWR) were obtained. The materials were ground and subjected to chemical analysis to determine the doses of $\mathrm{Pb}$ in the dry mass. The ground material was subjected to digestion with nitropercloric (nitric acid $(65 \% \mathrm{v} / \mathrm{v})$ and perchloric acids $(70 \% \mathrm{v} / \mathrm{v})$, Merck - 2:1) and $\mathrm{Pb}$ concentration was determined by atomic absorption spectrometry using a graphite oven (Perkin-Elmer Analyst 800). Quality control of the $\mathrm{Pb}$ analysis was ensured using certified reference material (NIST SRM 1573a sheet tomato) and blank reagents. Based on the $\mathrm{Pb}$ concentration and dry mass of each part of the plant, the cumulative $\mathrm{Pb}(\mu \mathrm{g} / \mathrm{pot})$ was calculated by multiplying the $\mathrm{Pb}$ content $\left(\mathrm{mg} \mathrm{g}^{-1}\right)$ by the dry mass (g).

Soil samples were taken from each pot after the last cutting of forages grasses, air-dried, and sieved $(<2 \mathrm{~mm})$. Available contents of $\mathrm{Pb}$ in soil samples were determined after extraction with Mehlich 1 (Embrapa, 1997) and 
diethylene-triaminepentaacetic acid - DTPA (Zhang et al., 2010) methods. The semitotal Pb content was determined using the USEPA 3051 method with digestion in a microwave oven with concentrated $\mathrm{HNO}_{3}(65 \%)$ of analytical purity (USEPA, 2007), and the total $\mathrm{Pb}$ content in the soil was determined using the USEPA 3052 method, with digestion in a microwave oven with $\mathrm{H}_{2} \mathrm{O}_{2}+\mathrm{HNO}_{3}+\mathrm{HF}$ and the addition of $\mathrm{H}_{3} \mathrm{BO}_{3}$ (USEPA, 2007). The $\mathrm{Pb}$ content was determined by atomic absorption spectrometry using a graphite oven (Perkin-Elmer Analyst 800). Quality control of the $\mathrm{Pb}$ analysis in the soil samples was conducted using certified soil (NIST SRM 2709 San Joaquin soil) and blank reagents.

\subsection{Statistical analysis}

To determine the critical dose toxicity (CDT) of $\mathrm{Pb}$, which reduced the growth of the plants by $10 \%$, a multivariate approach using the canonical variable analysis of joint variance of $\mathrm{Pb}$ doses was employed within each forage grass. The largest eigenvalue of the canonical variable was obtained from the scores of the vector of the observations for each experimental unit of the forage growth variables studied, reducing them to a single value. These scores were subjected to an analysis of joint variance, which consisted of the study of $\mathrm{Pb}$ doses within each forage grass. The regression equations were adjusted for the variables in the function of $\mathrm{Pb}$ doses after transformation the scores relative of the canonical variable for each forage. From the equations, it was estimated the $\mathrm{Pb}$ doses caused a reduction of $10 \%$ in the value of the scores relative of the canonical variable.
The concentration and accumulated $\mathrm{Pb}$ in the DWS, DWSB and DWR of the forages, as well as the $\mathrm{Pb}$ extracted from the soil using the different methods (Mehlich 1, DTPA, USEPA 3051 and USEPA 3052), were estimated by replacing the $\mathrm{CDT}$ in the equations relating to the $\mathrm{Pb}$ doses with these variables. For the accumulated $\mathrm{Pb}$, the percentage distribution in the CDT was determined in the DWS, DWSB and DWR of the forages.

Correlation studies were performed to evaluate the relationships between the $\mathrm{Pb}$ concentrations in soil determined by the different extraction methods (Mehlich 1, DTPA, USEPA 3051 and 3052), and the growth of the forage grasses determined by the canonical variable.

The transfer of $\mathrm{Pb}$ from the soil to the total dry weight (TDW), which refers to the aboveground part (DWS) + the stem base (DWSB), was calculated for each of the five forages as the transfer coefficient (ct). The formula is tc = TC / SC (USEPA, 2007), where tc: Pb transfer coefficient from soil to plants; TC: Total dry weight $\mathrm{Pb}$ concentration on dry matter basis ( $\mathrm{mg}$ $\left.\mathrm{kg}^{-1}\right)$, and $\mathrm{SC}$ : total $\mathrm{Pb}$ concentration in the soil $\left(\mathrm{mg} \mathrm{kg}^{-1}\right)$ in this case as extractable $\mathrm{Pb}$. Joint analyses of variance were conducted for the $\mathrm{Pb}$ doses within each forage cultivar. The regression equations were adjusted for each variable depending on the doses of $\mathrm{Pb}$.

\section{Results}

\subsection{Effects on plant growth and Pb uptake}

Multivariate analysis of variance (Manova) was applied to study the effect four $\mathrm{Pb}$ doses on variables dry weight of shoots (DWS), 
steam base (DWSB) and roots (DWR) of forage grasses. The results of Manova showed that $\mathrm{Pb}$ doses were statistically significant $(p<$ $0.01)$. Multivariate model of the first canonical variable $(\mathrm{VC}=0.0977 * \mathrm{DWS}+0.7987 * \mathrm{DWSB}$ $+0.2561 * \mathrm{DWR})$ totaled $92 \%$ of the total variation. This value is satisfactory in studies with this technique. The scores of the forages grasses growth canonical variable indicate that growth was reduced for all forages grasses with increasing $\mathrm{Pb}$ doses in the soil $(p<0.01)$. According to the coefficients of the fitted equations, the susceptibility of the cultivars forage grasses followed the pattern Xaraés $>$ Marandu $>$ Basilisk $>$ Tanzania $>$ Aruana (Figure 1).

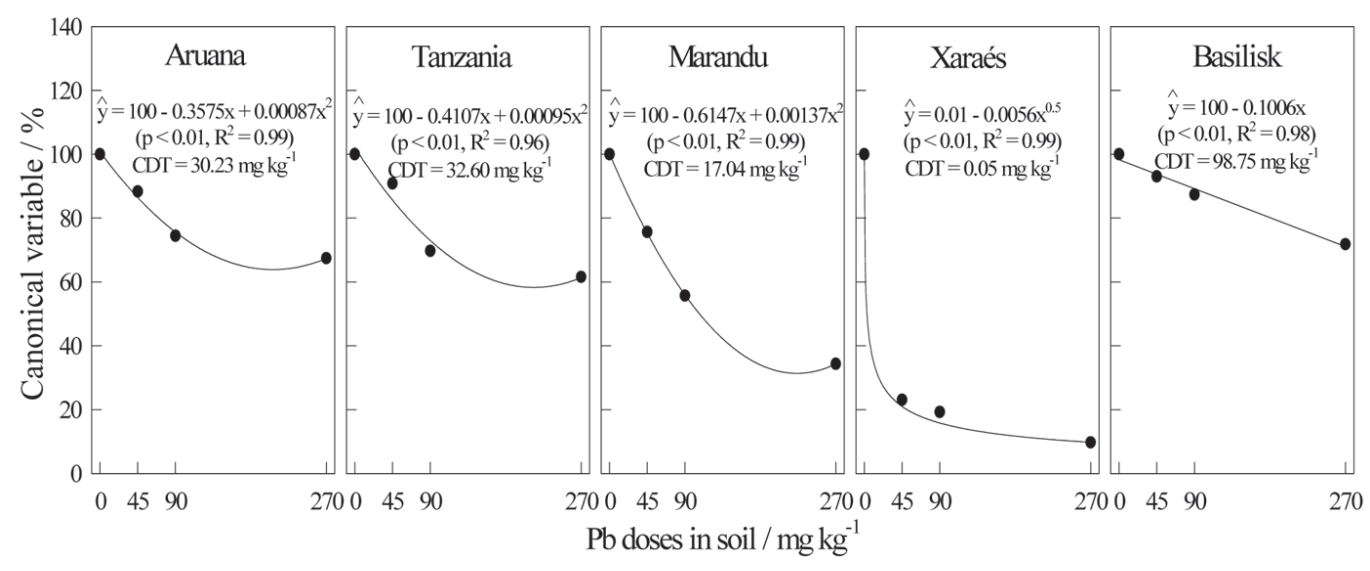

Figure 1. Relative score of the canonical variable of the multivariate analysis for forage grasses, depending on $\mathrm{Pb}$ doses applied to the soil and, critical dose toxicity (CDT) within 90 days of the initial cutting.

According to the curve of the canonical variable equations, the cultivar Xaraés was more susceptible to $\mathrm{Pb}$ than were the other cultivars. The cultivar Basilisk demonstrated more tolerance to $\mathrm{Pb}$ based on its observed toxicity critical dose (CDT) (Figure 1). The $\mathrm{CDT}$ of $\mathrm{Pb}$ necessary to reduce the growth of the forage grasses by $10 \%$ ranged from $0.1 \mathrm{mg} \mathrm{kg}^{-1}$ for cultivar Xaraés to $98.8 \mathrm{mg} \mathrm{kg}^{-1}$ for cultivar Basilisk (Figure 1).

Increases in $\mathrm{Pb}$ were observed in all plant parts of forage grasses as increasing doses of $\mathrm{Pb}$ were applied to the soil $(p<0.05)$. According to the coefficient of the adjusted equations, the concentration of $\mathrm{Pb}$ in the DWS at the highest dose $\left(270 \mathrm{mg} \mathrm{kg}^{-1}\right)$ ranged from 1.5 for the cultivar Tanzania to $2.3 \mathrm{mg} \mathrm{kg}^{-1}$ for the cultivar Xaraés. For the DWSB and DWR, the cultivars Basilisk and Xaraés showed similar $\mathrm{Pb}$ absorption characteristics (Table 2). The observed $\mathrm{Pb}$ doses ranged from $3.1 \mathrm{mg} \mathrm{kg}^{-1}$ for Basilisk to $7.5 \mathrm{mg} \mathrm{kg}^{-1} \mathrm{~Pb}$ for Xaraés in the DWSB and from $4.9 \mathrm{mg} \mathrm{kg}^{-1}$ for Basilisk to 11.4 $\mathrm{mg} \mathrm{kg}^{-1} \mathrm{~Pb}$ for Xaraés in the DWR. Also the 
coefficient of the adjusted equations, different cultivars tended to accumulate $\mathrm{Pb}$ similarly, with the doses of the different parts ordered roots $>$ stem base $>$ shoot (Table 2).

Table 2. Regression equations between the $\mathrm{Pb}$ concentration in the dry weight of forage grasses $(\hat{\mathrm{y}}$, $\mathrm{mg}\left[\mathrm{kg} \mathrm{DW}^{-1}\right)$ and $\mathrm{Pb}$ doses applied to the soil $\left(\mathrm{x}, \mathrm{mg} \mathrm{kg}^{-1}\right)$, and the critical level of toxicity (CLT, mg $[\mathrm{kg} \mathrm{DW}]^{-1}$ ) corresponding to the critical dose of toxicity (CDT) within 90 days of the initial cutting.

\begin{tabular}{llllrl}
\hline Dry weight & Forage grasses & Regression equation & $\mathrm{R}^{2}$ & $\mathrm{~F}$ test & CLT \\
\hline Shoot (DWS) & Aruana & $\hat{\mathrm{y}}=0.14+0.0905 \mathrm{x}^{0.5}$ & 0.99 & $76.1 * * *$ & 0.64 \\
& Tanzânia & $\hat{\mathrm{y}}=0.05+0.0908 \mathrm{x}^{0.5}$ & 0.93 & $113.2^{* * *}$ & 0.57 \\
& Marandu & $\hat{\mathrm{y}}=0.20+0.0062 \mathrm{x}$ & 0.98 & $174.5^{* * *}$ & 0.31 \\
& Xaraés & $\hat{\mathrm{y}}=0.28+0.0076 \mathrm{x}$ & 0.96 & $184.1^{* * *}$ & 0.28 \\
& Basilisk & $\hat{\mathrm{y}}=0.12+0.0064 \mathrm{x}$ & 0.99 & $190.1 * * *$ & 0.75 \\
Steam base (DWSB) & Aruana & $\hat{\mathrm{y}}=0.32+0.0135 \mathrm{x}$ & 0.98 & $130.6^{* * *}$ & 0.73 \\
& Tanzânia & $\hat{\mathrm{y}}=0.24+0.2351 \mathrm{x}^{0.5}$ & 0.98 & $81.8^{* * *}$ & 1.58 \\
& Marandu & $\hat{\mathrm{y}}=0.32+0.2165 \mathrm{x}^{0.5}$ & 0.94 & $34.5^{* * *}$ & 1.21 \\
& Xaraés & $\hat{\mathrm{y}}=0.31+0.4383 \mathrm{x}^{0.5}$ & 0.90 & $34.0^{* * *}$ & 0.41 \\
& Basilisk & $\hat{\mathrm{y}}=0.06+0.1855 \mathrm{x}$ & 0.95 & $116.6^{0 * 5 *}$ & 1.90 \\
& Aruana & $\hat{\mathrm{y}}=0.11+0.0199 \mathrm{x}$ & 0.99 & $141.4 * * *$ & 0.71 \\
& Tanzânia & $\hat{\mathrm{y}}=0.13+0.0206 \mathrm{x}$ & 0.98 & $160.8^{* * *}$ & 0.80 \\
& Marandu & $\hat{\mathrm{y}}=0.15+0.0234 \mathrm{x}$ & 0.97 & $111.8^{* * *}$ & 0.55 \\
& Xaraés & $\hat{\mathrm{y}}=0.15+0.0418 \mathrm{x}$ & 0.99 & $189.7 * * *$ & 0.02 \\
& Basilisk & $\hat{\mathrm{y}}=0.11+0.0179 \mathrm{x}$ & 0.99 & $127.8^{* * * *}$ & 1.88 \\
\hline
\end{tabular}

Significant at $* * * P=0.001$.

According to the coefficients of the fitted equations for the accumulation of $\mathrm{Pb}$, the cultivars expressed different patterns of accumulation behavior as increasing metal doses were applied to the soil $(p<0.05)$. Higher accumulation of $\mathrm{Pb}$ was observed in all plant parts with increased concentration applied in soil (Table 3). The cultivars Aruana, Tanzania, Marandu and Basilisk showed similar behaviors, following a decreasing order of $\mathrm{Pb}$ accumulation, roots $>$ shoot $>$ stem base. The cultivar Xaraés followed a decreasing order of metal accumulation, roots $>$ stem base $>$ shoot. 
Table 3. Regression equation between the $\mathrm{Pb}$ accumulations in the dry weight of forage grasses $(\hat{\mathrm{y}}, \mu \mathrm{g}$ pot $\left.^{-1}\right)$ and $\mathrm{Pb}$ doses applied to the soil $\left(\mathrm{x}, \mathrm{mg} \mathrm{kg}^{-1}\right)$, and the amount of the $\mathrm{Pb}$ accumulation (Pbaccum., $\mu \mathrm{g}$ pot $^{-1}$ ) corresponding to the critical dose of toxicity (CDT) within 90 days of the initial cutting.

\begin{tabular}{lllcrc}
\hline Dry weight & Forage grasses & Regression equation & $\mathrm{R}^{2}$ & $\mathrm{~F}$ test & CLT \\
\hline Shoot (DWS) & Aruana & $\hat{\mathrm{y}}=0.14+0.0905 \mathrm{x}^{0.5}$ & 0.99 & $76.1 * * *$ & 0.64 \\
& Tanzânia & $\hat{\mathrm{y}}=0.05+0.0908 \mathrm{x}^{0.5}$ & 0.93 & $113.2^{* * *}$ & 0.57 \\
& Marandu & $\hat{\mathrm{y}}=0.20+0.0062 \mathrm{x}$ & 0.98 & $174.5^{* * *}$ & 0.31 \\
& Xaraés & $\hat{\mathrm{y}}=0.28+0.0076 \mathrm{x}$ & 0.96 & $184.1^{* * *}$ & 0.28 \\
& Basilisk & $\hat{\mathrm{y}}=0.12+0.0064 \mathrm{x}$ & 0.99 & $190.1^{* * *}$ & 0.75 \\
Steam base (DWSB) & Aruana & $\hat{\mathrm{y}}=0.32+0.0135 \mathrm{x}$ & 0.98 & $130.6 * * *$ & 0.73 \\
& Tanzânia & $\hat{\mathrm{y}}=0.24+0.2351 \mathrm{x}^{0.5}$ & 0.98 & $81.8^{* * *}$ & 1.58 \\
& Marandu & $\hat{\mathrm{y}}=0.32+0.2165 \mathrm{x}^{0.5}$ & 0.94 & $34.5^{* * *}$ & 1.21 \\
& Xaraés & $\hat{\mathrm{y}}=0.31+0.4383 \mathrm{x}^{0.5}$ & 0.90 & $34.0^{* * *}$ & 0.41 \\
Roots (DWR) & Basilisk & $\hat{\mathrm{y}}=0.06+0.1855 \mathrm{x}^{0.5}$ & 0.95 & $116.6^{* * *}$ & 1.90 \\
& Aruana & $\hat{\mathrm{y}}=0.11+0.0199 \mathrm{x}$ & 0.99 & $141.4 * * *$ & 0.71 \\
& Tanzânia & $\hat{\mathrm{y}}=0.13+0.0206 \mathrm{x}$ & 0.98 & $160.8 * * *$ & 0.80 \\
& Marandu & $\hat{\mathrm{y}}=0.15+0.0234 \mathrm{x}$ & 0.97 & $111.8^{* * *}$ & 0.55 \\
& Xaraés & $\hat{\mathrm{y}}=0.15+0.0418 \mathrm{x}$ & 0.99 & $189.7 * * *$ & 0.02 \\
& Basilisk & $\hat{\mathrm{y}}=0.11+0.0179 \mathrm{x}$ & 0.99 & $127.8^{* * *}$ & 1.88 \\
\hline
\end{tabular}

Significant at $* * \mathrm{P}=0.01, * * * P=0.001$.

At the highest dose of the metal $\left(270 \mathrm{mg} \mathrm{kg}^{-1}\right.$ $\mathrm{Pb}), \mathrm{Pb}$ accumulated most in the cultivar Aruana, with doses of 18.0, 12.7 and $22.3 \mu \mathrm{g}$ per pot in the shoots, stem base and roots, respectively. The lowest level of accumulation was observed in the cultivar Xaraés, with 1.5, 1.9 and 4.1 $\mu \mathrm{g}$ per pot in the shoots, stem base and roots, respectively. The cultivar Xaraés also had the smallest critical toxicity doses (CDT) of the studied varieties (Table 3) with 0.7, 0.2 and 0.4 $\mu \mathrm{g}$ per pot $\mathrm{Pb}$ in the DWS, DWSB and DWR, respectively. The greatest CDT values were observed in the cultivar Aruana for the shoot (10.5 $\mu \mathrm{g}$ per pot), cultivar Tanzania in the stem base $(4.3 \mu \mathrm{g}$ per pot) and cultivar Basilisk in the roots $(6.1 \mu \mathrm{g}$ per pot), suggesting that there is no relationship between CDT and the accumulation of $\mathrm{Pb}$ in different plant parts. Accumulation is dictated by the $\mathrm{Pb}$ content of the plant tissues and dry matter production of the forage cultivars. It is noteworthy that, although the cultivar Xaraés exhibited the highest $\mathrm{Pb}$ concentrations in its parts (Table 2) due its low growth, its total $\mathrm{Pb}$ accumulation was $85.9 \%$ lower than that of the cultivar Aruana, which had the greatest $\mathrm{Pb}$ accumulation (Table 3).

The percentage distribution of the $\mathrm{Pb}$ accumulation in different parts of the forages grasses (Figure 2) corroborates the results obtained using the CDT (Table 3). Higher percentage of accumulation of $\mathrm{Pb}$ in the $\mathrm{CDT}$, was observed in the shoot in comparison with the other parts of the studied forage grasses cultivars (Figure 2). The decreasing order of $\mathrm{Pb}$ accumulation as analyzed by CDT for the cultivars Tanzania and Marandu followed the 
order shoot $>$ stem base $>$ roots. The cultivars Aruana, Xaraes and Basilisk followed the descending order shoot $>$ root $>$ stem base. All of the forage cultivars had a higher $\mathrm{Pb}$ accumulation in the CDT in the shoots (Table 3). The cultivar Aruana was particularly resilient, with the highest percentage of $\mathrm{Pb}$ accumulation (61\%) among the cultivars found in the DWS.

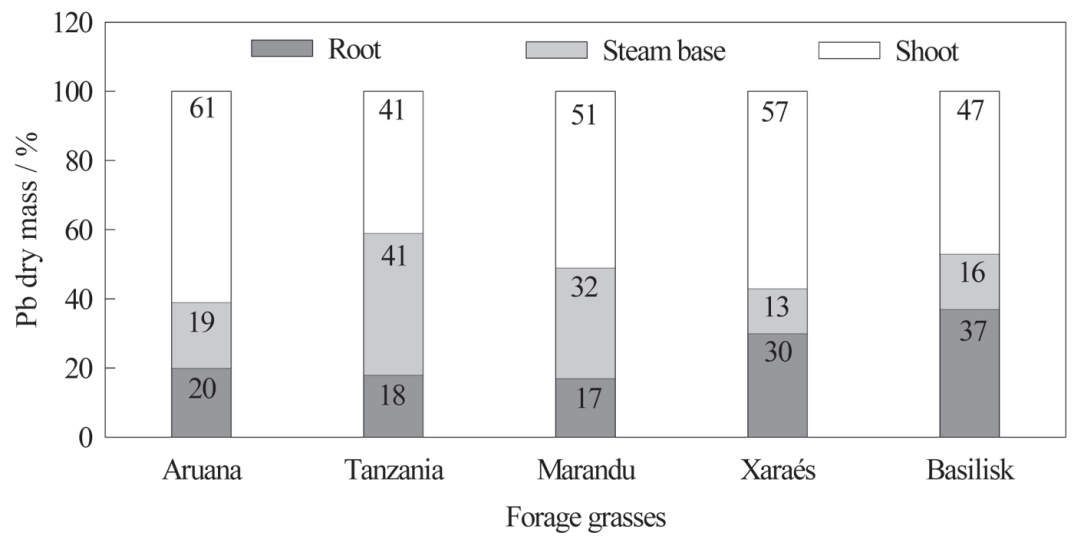

Figure 2. Percentage distribution of $\mathrm{Pb}$ accumulation in the shoot, stem base and roots dry mass at the critical dose of toxicity (CDT) for forage grasses within 90 days of the initial cutting.

Table 4. Regression equations between the $\mathrm{Pb}$ concentration in soil extracted using the Mehlich 1 , DTPA, USEPA 3051 and USEPA 3052 methods $\left(\hat{y}, \mathrm{mg} \mathrm{kg}^{-1}\right.$ ) and $\mathrm{Pb}$ doses applied to the soil (x, mg kg ${ }^{1}$ ), and the critical level of toxicity (CLT, $\mathrm{mg} \mathrm{kg}^{-1}$ ) corresponding to the critical dose of toxicity (CDT) within 90 days of the initial cutting.

\begin{tabular}{|c|c|c|c|c|c|}
\hline Method & Forage grasses & Regression equation & $\mathrm{R}^{2}$ & F test & CLT \\
\hline \multirow[t]{5}{*}{ Mehlich 1} & Aruana & $\hat{y}=0.6326 x$ & 0.99 & $245.8 * * *$ & 19.12 \\
\hline & Tanzânia & $\hat{y}=0.5054 x$ & 0.99 & $198.7 * * *$ & 16.48 \\
\hline & Marandu & $\hat{y}=0.6132 x$ & 0.99 & $166.2 * * *$ & 10.45 \\
\hline & Xaraés & $\hat{y}=0.5347 x$ & 0.99 & $223.1^{* * *}$ & 0.03 \\
\hline & Basilisk & $\hat{y}=0.5056 x$ & 0.99 & $187.8^{* * * *}$ & 49.93 \\
\hline \multirow[t]{5}{*}{ DTPA } & Aruana & $\hat{y}=0.8005 x$ & 0.98 & $118.4 * * *$ & 24.20 \\
\hline & Tanzânia & $\hat{y}=0.7284 x$ & 0.99 & $145.1^{* * *}$ & 23.75 \\
\hline & Marandu & $\hat{y}=0.7783 x$ & 0.98 & $131.2 * * *$ & 13.26 \\
\hline & Xaraés & $\hat{y}=0.7415 x$ & 0.99 & $294.7 * * *$ & 0.04 \\
\hline & Basilisk & $\hat{y}=0.7787 x$ & 0.98 & $158.7 * * *$ & 76.87 \\
\hline \multirow[t]{5}{*}{ USEPA 3051} & Aruana & $\hat{y}=0.8762 x$ & 0.99 & 284.7 *** & 26.49 \\
\hline & Tanzânia & $\hat{y}=0.9284 x$ & 0.99 & $222.8 * * *$ & 30.27 \\
\hline & Marandu & $\hat{y}=0.8068 x$ & 0.99 & $198.6^{* * *}$ & 13.75 \\
\hline & Xaraés & $\hat{y}=0.8623 x$ & 0.99 & $215.3 * * *$ & 0.04 \\
\hline & Basilisk & $\hat{y}=0.9041 x$ & 0.99 & $208.6 * * *$ & 89.28 \\
\hline \multirow[t]{5}{*}{ USEPA 3052} & Aruana & $\hat{y}=0.9055 x$ & 0.99 & $232.8^{* * *}$ & 27.37 \\
\hline & Tanzânia & $\hat{y}=0.9044 x$ & 0.99 & $223.9 * * *$ & 29.48 \\
\hline & Marandu & $\hat{y}=0.8377 x$ & 0.99 & $264.8^{* * *}$ & 14.27 \\
\hline & Xaraés & $\hat{y}=0.9066 x$ & 0.99 & $242.5 * * *$ & 0.05 \\
\hline & Basilisk & $\hat{y}=0.9507 x$ & 0.98 & $229.2 * * *$ & 93.88 \\
\hline
\end{tabular}

Significant at $* * * P=0.001$. 


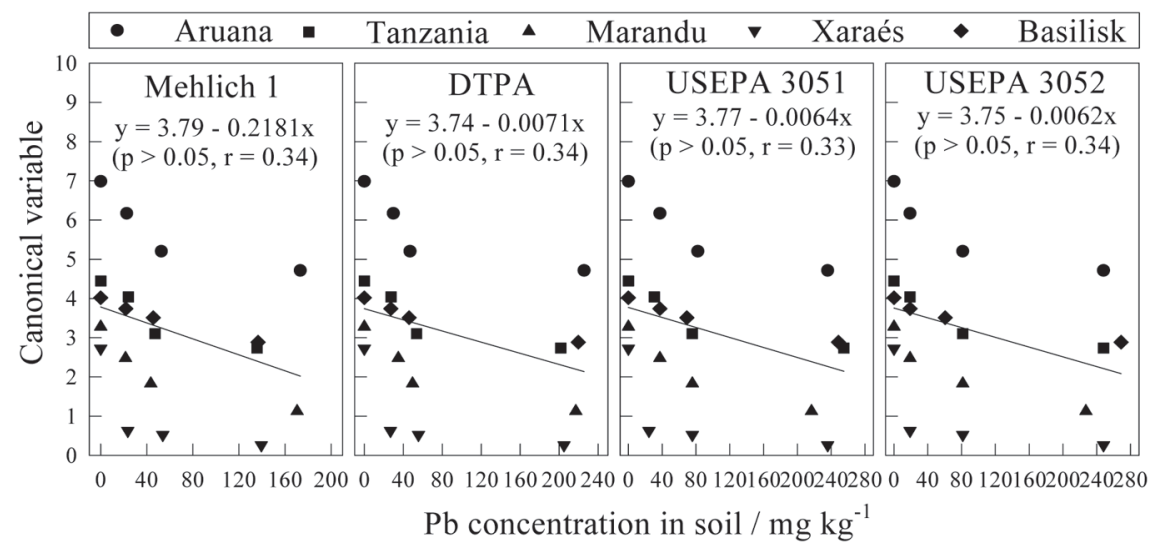

Figure 3. Relationship between the growths of forage grasses evaluated by the canonical variable and extraction methods (Mehlich 1, DTPA, USEPA 3051 and USEPA 3052) within 90 days of the initial cutting.

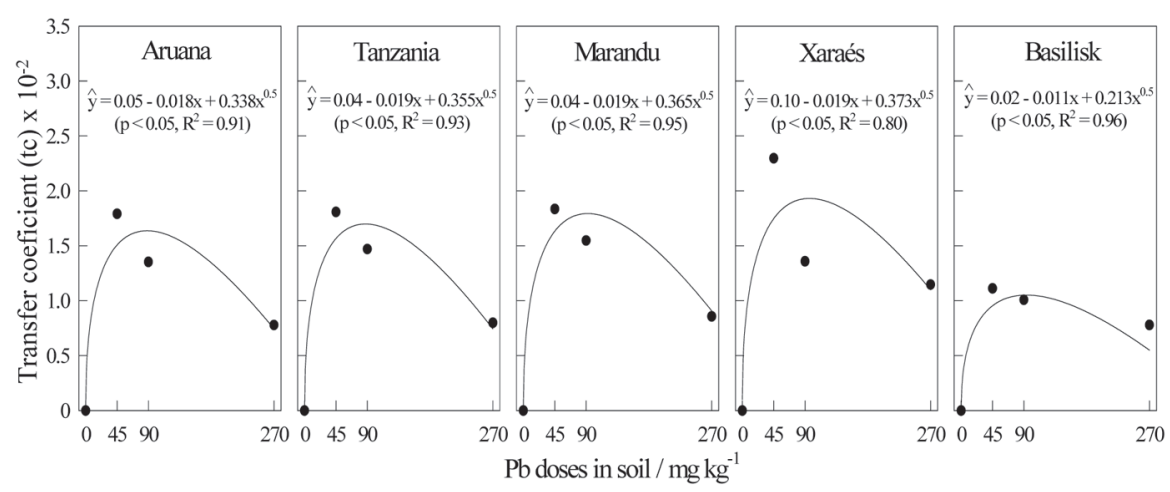

Figure 4. Transfer coefficient (tc) (ratio between plant shoot $\mathrm{Pb}, \mathrm{mg} \mathrm{kg}^{-1}$ per total $\mathrm{Pb}$ in soil, $\mathrm{mg} \mathrm{kg}^{-1}$ ) of the forage grasses due to $\mathrm{Pb}$ doses applied to the soil over a period of 90 days from the initial cutting

\subsection{Lead concentration in soil}

Lead concentration in soil increased according to the increasing concentration applied $(p<$ $0.05)$. The concentration of $\mathrm{Pb}$ in soil obtained using the Mehlich 1, DTPA, USEPA 3051 and USEPA 3052 extraction methods, according to the coefficient of the adjusted equations, showed an increase of measured $\mathrm{Pb}$ doses applied to the soil were increased (Table 4). The highest concentration of $\mathrm{Pb}$ in soil was obtained using the total extraction method (USEPA 3052), followed by the USEPA 3051, DTPA and Mehlich 1 methods. 
Table 4. Regression equations between the $\mathrm{Pb}$ concentration in soil extracted using the Mehlich 1, DTPA, USEPA 3051 and USEPA 3052 methods ( $\hat{y}, \mathrm{mg} \mathrm{kg}-1$ ) and $\mathrm{Pb}$ doses applied to the soil (x, mg kg-1), and the critical level of toxicity (CLT, mg kg-1) corresponding to the critical dose of toxicity (CDT) within 90 days of the initial cutting.

The average percentages of $\mathrm{Pb}$ recovered by the extraction methods at the highest dose of the metal were $56 \%$ for Mehlich 1, 79\% for DTPA, $89 \%$ for USEPA 3051 and 93\% for USEPA 3052. The highest doses of soil $\mathrm{Pb}$ were extracted using the USEPA 3052 method, which consists of a mixture of strong acids $\left(\mathrm{H}_{2} \mathrm{O}_{2}+\right.$ $\mathrm{HNO}_{3}+\mathrm{HF}+\mathrm{H}_{3} \mathrm{BO}_{3}$ ) (Hseu, 2004). In strongly acidic solutions, the total content of the element in the soil can be obtained, i.e., the reserves of the metal in the soil are measured, in addition to the exchangeable and soluble fractions. The critical level of toxicity (NCT) of Pb necessary to reduce the growth of the forages grasses by $10 \%$ ranged from 0.03 to $93.88 \mathrm{mg} \mathrm{kg}^{-1} \mathrm{~Pb}$ in the soil, emphasizing the differences in sensitivity between forage cultivars (Table 4). No extractor used in this study was efficient at predicting the bioavailability of $\mathrm{Pb}$ in the soil for forage grasses (Figure 3), as indicated by the non-significance of the correlations $(p>0.05)$.

The ability of the plants to extract soil $\mathrm{Pb}$ was evaluated by the transfer factor or transfer coefficient (tc), using the ratio between $\mathrm{Pb}$ in the total dry weight (TDW) (shoot + stem base) per total $\mathrm{Pb}$ in the soil in $\mathrm{mg} \mathrm{kg}^{-1}$. The tc for $\mathrm{Pb}$ in TDW was varied with cultivar and metal dose $(p<0.05)$. For all $\mathrm{Pb}$ doses in the soil, the smallest ct values were observed in the cultivar Basilisk and the largest ct values were observed in the cultivar Xaraés, further demonstrating the tolerance of the former cultivar to environmental contamination (Figure 4). The values of tc ranged from 0.010 to 0.017 at $45 \mathrm{mg} \mathrm{kg}^{-1}$ of $\mathrm{Pb}$ in the soil, 0.010 to 0.019 at $90 \mathrm{mg} \mathrm{kg}^{-1}$ of $\mathrm{Pb}$ in the soil, and 0.005 to 0.011 at $270 \mathrm{mg} \mathrm{kg}^{-1}$ of $\mathrm{Pb}$ in the soil.

\section{Discussion}

The observed range of CDT values indicates that different forage grasses cultivars have different $\mathrm{Pb}$ sensitivity, which may be associated with various nutritional or physiological disorders, genetic backgrounds and metabolic characteristics (Sharma and Dubey, 2005). In agreement with these results, reduced growth has been observed in two species of vetiver grass (Vetiveria zizanioides and Vetiveria nemoralis) (Chantachon et al., 2004), due to increases in soil $\mathrm{Pb}$ concentrations.

Based on the canonical variable scores, the observed reductions in growth compared to the control were $27 \%$ for Basilisk, $37 \%$ for Tanzania, 38\% for Aruana, 54\% for Marandu and 89\% for Xaraés cultivar at the highest dose of the metal (270 $\mathrm{mg} \mathrm{kg}^{-1} \mathrm{~Pb}$ ). In a study evaluating the effects of increased soil $\mathrm{Pb}$ content on the growth of Plantago major, Kosobrukhov et al. (2004) reported reductions in the dry weight of whole plants ranging from $30 \%$ in soil contaminated with $500 \mathrm{mg} \mathrm{kg}^{-1} \mathrm{~Pb}$ to $46 \%$ in soil contaminated with 2,000 $\mathrm{mg} \mathrm{kg}^{-1} \mathrm{~Pb}$ relative to control.

Some metals, particularly $\mathrm{Pb}$, are insoluble and cannot move freely in the vascular system of the plant because these toxic elements may be immobilized in the apoplastic and symplastic compartments by the formation of precipitated 
sulfates, carbonates and phosphates (Raskin et al., 1997). The apoplastic transport of these elements is further more limited by the high cation exchange capacity of the cell walls, however this effect is mitigated for metal absorbed in the form chelated not cationic (Raskin et al., 1997). The highest doses of $\mathrm{Pb}$ were observed in the roots of plants, a result that corresponds with the low mobility of $\mathrm{Pb}$ in plants reported in the literature (Martin et al., 2006). Martin et al. (2006) did not detect any translocation of $\mathrm{Pb}$ from the roots to the shoots in several plant species (Allium schoenoprasum L., Lactuca sativa L., Phaseolus vulgaris L., and Raphanus sativus L. and Spinacia oleracea L.) cultivated in soil contaminated with $90 \mathrm{mg}$ $\mathrm{kg}^{-1}$ of the metal, even considering the higher amounts absorbed by Phaseolus vulgaris L. The $\mathrm{Pb}$ concentrations observed in the different parts of the forage varieties in this study were below the range of $\mathrm{Pb}$ toxicity to plants, which was previously reported to range from 30 to $300 \mathrm{mg} \mathrm{kg}{ }^{-1}$ dry mass (Kabata-Pendias and Pendias, 2001). Similar results were observed in tomato seedlings; there was an increase in the concentration of $\mathrm{Pb}$ in plant tissues with an increased metal dose in the soil, and higher concentrations of $\mathrm{Pb}$ were observed in the roots compared to the shoot (Akinci et al., 2010).

The lead is generally present as the ion $\mathrm{Pb}^{2+}$ (Kabata-Pendias and Pendias, 2001), consequently the low mobility of $\mathrm{Pb}$ in the soil can be explained by the formation of stable complexes between the metal and inorganic $\left(\mathrm{Cl}^{-}, \mathrm{CO}_{3}^{2-}\right)$ or organic (humic and fulvic acids) ligands present in the soil (Zhang et al., 2013). The metal may also form low-solubility complexes with carbonates, sulfates and phosphates, in addition to becoming associated with clay minerals; the oxides of $\mathrm{Mn}, \mathrm{Fe}$ and $\mathrm{Al}$; and hydroxides. The metal may also be concentrated in $\mathrm{Ca}$ carbonates. The addition of a chelating agent increases the availability of $\mathrm{Pb}$ (Butcher, 2009). The availability of the metal is also highly influenced by soil $\mathrm{pH}$ and is favored in an acidic environment (Kabata-Pendias and Pendias, 2001), with a strong tendency for $\mathrm{Pb}$ to accumulate on the surface of the soil. This greater accumulation of $\mathrm{Pb}$ in the surface layer is partly associated with the organic matter content of the soil, which decreases with depth (Szopka et al., 2013). Greater mobility of $\mathrm{Pb}$ was found in soil with the following characteristics: higher doses of sand (quartz), lower cation-exchange capacity (CEC) rates and lower rates of organic matter (Violante et al., 2010). These characteristics resulted in higher $\mathrm{Pb}$ bioavailability and demonstrated their importance in the adsorption of metal to the soil.

The critical dose toxicity (CDT) in DWS, DWSB and DWR ranged from 0.28 to 0.75 , 0.41 to 1.90 and 0.02 to $1.54 \mathrm{mg} \mathrm{kg}^{-1} \mathrm{~Pb}$ in the cultivars Xaraés and Basilisk, respectively, demonstrating that the latter variety had a higher tolerance to the metal in all of its components at the highest dose of the element (Table 2). These results are in agreement with those observed for the CDT of these forage varieties using the canonical variable scores (Figure 1). Different species of plants subjected to similar growth conditions and heavy metal concentrations react differently depending on their specificity of uptake, accumulation and tolerance to the elements (Martin et al., 2006).

The $\mathrm{Pb}$ doses observed in the DWS, DWSB and DWR of the forage grasses (Table 2) were below 
the limit of $30 \mathrm{mg} \mathrm{kg}^{-1} \mathrm{~Pb}$ that was considered acceptable for bovine diets by the NRC (1996), suggesting that these varieties could be used in the feeding of ruminants. Miranda et al. (2012), working with the cultivars Basilisk, Marandu, Xaraés, Tanzania and Brachiaria ruziziensis in soil contaminated by the deposition of solid waste, found an average content of $0.48 \mathrm{mg}$ $\mathrm{Pb} \mathrm{kg}^{-1}$ in the plants, lower than that observed in the present study. These differences may be related to differences in metabolism, anatomy and physiology between species.

The highest concentrations of $\mathrm{Pb}$ were observed in the roots of the forages grasses, a result that is in agreement with other authors, who reported that $\mathrm{Pb}$ when absorbed by the plant tends to concentrate in roots, translocating very little to the shoot, which varies between different plant species (Zang et al., 2013). In maize, it was found that when increasing doses of $\mathrm{Pb}$ in the soil increased the doses of the element, particularly in plant roots (Mojiri, 2011). The retention of $\mathrm{Pb}$ in the cell wall in the roots occurs due to links to the sites cation exchange and precipitation extracellular, mainly in the form of carbonates of $\mathrm{Pb}$ (Jarvis and Leung, 2002). These results may be related with immobilization of the element by means of insoluble organic complexes present in the plant tissue

For a plant to be an efficient extractor of metal from the soil, it must have a high dry matter production because the two criteria are directly related; the cultivar Xaraés, therefore, has a low phytoremediation capability in soils contaminated by $\mathrm{Pb}$. Average concentrations of $1,053 \mathrm{mg} \mathrm{kg}^{-1} \mathrm{~Pb}$ (in the presence of a chelating agent, $10 \mathrm{mmol} \mathrm{kg}{ }^{-1}$ EDDS - ethylenediamine$\mathrm{N}, \mathrm{N}^{\prime}$-disuccinic acid) were found in Cannabis sativa that was grown in soil with a total $\mathrm{Pb}$ content of $1,100 \mathrm{mg} \mathrm{kg}^{-1}$ (Kos et al., 2003). Doses of $1,820 \mathrm{mg} \mathrm{kg}^{-1}$ and $1,927 \mathrm{mg} \mathrm{kg}^{-1} \mathrm{~Pb}$ were observed in the shoots and roots of Kochia chenopodiaceae (native to Iran), respectively, grown in a soil with a total $\mathrm{Pb}$ content of 5,369.6

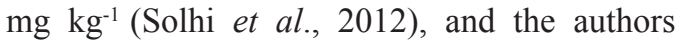
therefore claim that the plant has a high metal tolerance capacity.

Hyperaccumulator plants have the ability to store high concentrations of heavy metals, ranging from 100 to $10,000 \mathrm{mg} \mathrm{kg}^{-1}$ dry weight depending on the metal. $\mathrm{Pb}$ hyperaccumulators are able to extract and accumulate more than $1,000 \mathrm{mg} \mathrm{kg}^{-1}$ dry weight $\mathrm{Pb}$ in their tissues (Raskin et al., 1997). None of the forage cultivars studied displayed hyperaccumulator characteristics; although the concentrations of $\mathrm{Pb}$ in these plants were satisfactory (Table 2), the cumulative amount of $\mathrm{Pb}$ extracted was low (Table 3) due to the resulting reduction of growth (Figure 1). Therefore, these forages cultivars have little potential for phytoextraction, unlike castor, which is an efficient hyperaccumulator of $\mathrm{Pb}$ (Romeiro et al., 2006). However, the studied varieties could be used in phytostabilization, especially the cultivar Basilisk, which proved to be quite tolerant to $\mathrm{Pb}$.

Features, such as high translocation levels and the accumulation of toxic elements in different plant parts, mainly in the shoots, are desirable in phytoextraction programs. However, in this work, higher $\mathrm{Pb}$ concentrations in the roots and stem base of the forages grasses were desirable so that the shoot portions of the plants could be used as animal feed. This pattern was not observed in the percentage distribution of $\mathrm{Pb}$ accumulation in the CDT (Figure 2), indicating 
that caution should be taken when feeding animals with forages grasses grown in soils contaminated with $\mathrm{Pb}$. Therefore, although $\mathrm{Pb}$ levels in the shoots of the forages grasses are less than the maximum limit of $30 \mathrm{mg} \mathrm{kg}^{-1}$ acceptable in bovine diets (NRC, 1996), special attention should be given to the possible bioaccumulation of metal in the food chain, which may endanger human health.

This measurement does not correspond to the actual availability of $\mathrm{Pb}$ to plants, but it is the most suitable method for the analysis of environmental quality. A higher soil $\mathrm{Pb}$ concentration was obtained using the DTPA method compared to the Mehlich 1 method, demonstrating that the latter technique is less suited to the assessment of available $\mathrm{Pb}$. Solutions of complexing agents, mainly DTPA, have been employed for the extraction of exchangeable heavy metals and preferentially associate with organic matter in both biosolid-treated and untreated soils. DTPA is the official extraction method for cationic micronutrients $(\mathrm{Cu}, \mathrm{Fe}, \mathrm{Mn}$ e $\mathrm{Zn})$ in the state of São Paulo, Brazil (Abreu et al., 2002). The Mehlich 1 method, conversely, has been widely used in routine laboratories in Minas Gerais, Brazil. The Environmental Protection Agency of the United States (USEPA, 1997) recommends the determination of the total metal content in a sample using the USEPA 3052 method.

In clay soil (Oxisol), the DTPA and Mehlich 3 methods have been found to extract similar amounts of $\mathrm{Pb}$, while the Mehlich 1 method extracted smaller amounts of this element; the presence of sulfate in this extractor resulted in the formation of lead sulfate, which inhibited the detection of the metal (Zhang et al., 2010), and this result is in agreement with the present study. The results obtained by these authors are directly related to the digestion processes of each methodology, as well as the types and concentrations of acids used.

Across a range of soil types, Zang et al. (2013) found that $\mathrm{Pb}$ was higher in the organic and residual fractions and was concentrated mainly in the residual fraction, leading to the high retention, low mobility and low availability of this element in the soil. The DTPA, Mehlich 3 and Mehlich 1 extraction methods were effective for evaluating $\mathrm{Pb}, \mathrm{Cd}, \mathrm{Cu}$ and $\mathrm{Zn}$ (Zhang et al., 2010). However, the $\mathrm{Pb}$ levels found in the present study using the Mehlich 1 method agree with those obtained by the previous authors, which is in contrast with the levels found using the DTPA method (Finzgar et al., 2006).

The critical level of toxicity (CLT) indicates the $\mathrm{Pb}$ concentration in the soil at which the growth of a plant decreases by $10 \%$ (Table 4), and for all of the studied forages grasses cultivars (except the cultivar Basilisk), this value is below the levels considered phytotoxic by KabataPendias and Pendias (2001), who reported that doses between 30 to $300 \mathrm{mg} \mathrm{kg}^{-1} \mathrm{~Pb}$ can cause serious damage to plants. The largest CLT values were observed in the cultivar Basilisk, in agreement with the canonical variable score (Figure 1), demonstrating that this cultivar had greater tolerance to $\mathrm{Pb}$. The lowest CLT values were observed in the cultivar Xaraés, supporting that this cultivar had the greatest sensitivity to $\mathrm{Pb}$, as further evidenced by the lower metal accumulation in its total dry mass (Table 3). Previously reported CLT values for $\mathrm{Pb}$ in Cordia trichotoma, Peltophorum dubium and Piptadenia gonoacantha were lower than $1.0 \mathrm{mg}$ $\mathrm{kg}^{-1}$, which was below the range established by Kabata-Pendias and Pendias (2001) (Marques et 
al., 2000). However, these authors emphasized that the differences observed between plants should be interpreted with caution due to possible contamination and interactions between chemicals in the soil and the physiologies of the plants. In an analysis of $\mathrm{Cd}, \mathrm{Cr}, \mathrm{Pb}$ and $\mathrm{Zn}$ levels using the digestion methods, no correlations were observed between metal concentration and the grain yield of maize (Nogueira et al., 2008). In another study, no significant correlation coefficients were observed between corn or sorghum and $\mathrm{Pb}$ extracted from the ground using the methods: DTPA, $\mathrm{HCl} 0.1 \mathrm{~mol} \mathrm{~L}^{-1}$, Mehlich 1 and 3 (He et al., 1991). These results corroborate those observed in the present study.

The extraction methods used in this study are poor indicators of bioavailability $\mathrm{Pb}$, particularly the Mehlich 1 and DTPA methods. The availability of $\mathrm{Pb}$ in the soil is rapidly reduced by its strong interactions with $\mathrm{Fe}$ and $\mathrm{Al}$ oxides and clay (Violante et al., 2010), explaining the low correlation of this element in the present study ( $\mathrm{r}$ $\approx 0.34$ ). An extractor with a principal chelation agent (diethylene-triaminepentaacetic acid and triethanolamine DTPA-TEA) was not effective in predicting the availability of $\mathrm{Pb}, \mathrm{Cd}, \mathrm{Cr}, \mathrm{Cu}$, $\mathrm{Ni}$ and $\mathrm{Zn}$ to sunflower (Helianthus annuus L.), black oat (Avena strigosa Schreber) or grassbatatais (Paspalum notatum Flügge) that were cultivated in contaminated soils (Andrade et al., 2009). According to these authors, the lower correlation observed for the DTPA-TEA method compared to the acidic methods reflects their distinct principles of extraction. The DTPA-TEA method works via complexation, which is more efficient at extracting metals associated with organic matter, while the acid methods work via etching and more easily extract metals adsorbed in a crystal lattice of minerals (full or partial solubilization of minerals).

No significant correlations were observed between the amounts of $\mathrm{Pb}$ absorbed by tobacco plants with contents extracted from the soil using the Mehlich 1 and 3 methods and the DTPA method, further confirming the results obtained in the present work (Mulchi et al., 1991). However, a different result was found by Abreu et al. (2002), who claimed that the DTPA and Mehlich 3 methods proved promising for assessing the availability of $\mathrm{Pb}$ in the soil for Brachiaria sp., Pennisetum purpureum Schumach and Imperata brasiliensis Trin. This is one of the few studies in which the results obtained using chemical extractants were effective in estimating the availability of $\mathrm{Pb}$ to plants.

A review of the literature indicates that the results obtained using different extraction methods (water, salt, acid, chelating or mixed solutions) are generally not effective at evaluating the availability of $\mathrm{Pb}$ (Abreu et al., 2002). Identifying an extractor that simulates the chemical processes of roots in contact with contaminated soil therefore remains a major challenge for researchers.

The results of this research indicate that $\mathrm{Pb}$ is translocated more readily to the shoot at lower levels, confirming previous results that observed considerably higher metal accumulation in the roots in the presence of elevated contaminant levels (Almeida et al., 2007). This result may be related to the immobilization of this element by insoluble complexes present in plant tissues, suggesting that this mechanism may be a 
survival trait of the forage grasses studied. These results were below the average ct of 0.045 found for the vegetables spinach, lettuce, carrots and radishes cultivated in soil contaminated with $100 \mathrm{mg} \mathrm{kg}^{-1} \mathrm{~Pb}$ (Intawongse and Dean, 2008). The tc values for all forage cultivars in this work were within the range of tc values for $\mathrm{Pb}$ indicated in the literature: 0.01 to 0.1 (Kloke et al., 1984) for doses of 45 and $90 \mathrm{mg} \mathrm{kg}^{-1}$ of $\mathrm{Pb}$ in the soil. At the highest dose $\left(270 \mathrm{mg} \mathrm{kg}^{-1} \mathrm{~Pb}\right.$ in the soil), only the cultivar Xaraés fell in this range of values.

The translocation process is mainly controlled by mechanisms: the pressure of root and leaf transpiration and also the solubility of the metal in the soil, but this is restricted due to its adsorption to particles of mineral fractions (Violante et al., 2010). This adsorption is particularly prevalent for $\mathrm{Pb}$, which is known to have little mobility in the soil. To maximize the potential for the phytoextraction of $\mathrm{Pb}$ from the soil, the solubility of the metal should be enhanced using synthetic chelators (Butcher, 2009), as increases in the transfer coefficient leads to increases in the absorption of the contaminant.

Determining the transfer coefficient (tc), i.e., the concentration of the metal in the aerial part of plant in relation to the total concentration in the soil is a convenient method to quantify differences in the bioavailability of metals to plants. Some metals, such as $\mathrm{Cd}$ and $\mathrm{Zn}$, have higher transfer coefficients, reflecting their weak soil sorption characteristics, while others, such as $\mathrm{Cu}, \mathrm{Cr}$ and $\mathrm{Pb}$, have low coefficients because they are strongly linked to soil colloids, which make them less bioavailable (Violante et al., 2010).

\section{Conclusion}

Increasing doses of $\mathrm{Pb}$ in the soil caused reduction of the growth in all of the forage varieties studied. The cultivar Basilisk was generally the most tolerant to $\mathrm{Pb}$, and the cultivar Xaraés was generally the most susceptible to $\mathrm{Pb}$. The lower transfer coefficient of the cultivar Basilisk, due to the high content and accumulation of $\mathrm{Pb}$ in its roots, makes it the most suitable for phytoremediation programs, with possible uses in pasture areas. None of forage cultivars were $\mathrm{Pb}$ hyperaccumulators. The Mehlich 1, DTPA, USEPA 3051 and USEPA 3052 extraction methods indicated different doses of $\mathrm{Pb}$ in the soil, and the Mehlich 1 method had the lowest level of metal extraction from the soil. No correlation was observed between the forage grasses growth and the measurement of $\mathrm{Pb}$ in soil by the studied extraction methods, especially for the Mehlich 1 and DTPA methods, suggesting the inefficiency of these techniques for determining the phytoavailability of $\mathrm{Pb}$.

\section{Acknowledgments}

The Coordination for the Improvement of Higher Level Personnel (Capes) provided a graduate student stipend. The Department of Soil Science, ESALQ, University of São Paulo provided the laboratory analysis of soil samples. The Federal University of the Jequitinhonha and Mucuri (UFVJM) provided the infrastructure needed to conduct this study. 


\section{References}

Abreu, C.A., Abreu, M.F., Berton, R.S. 2002. Chemical analysis of soil for heavy metals. In: Alvarez V., V.H., Schaefer, C.E.G.R., Barros, N.F., Mello, J.W.V., Costa, L.M. Topics in soil science. v.2. Brazilian Society of Soil Science, Viçosa, Brazil, pp: 644-692

Akinci, I.E., Akinci, S., Yilmaz, K. 2010. Response of tomato (Solanum lycopersicum L.) to lead toxicity: growth, element uptake, chlorophyll and water content. Afr. J. Agric. Res., 5, 416-423.

Almeida, A.A.F., Valle, R.R., Mielke, M.S., Gomes, F.P. 2007. Tolerance and prospection of phytoremediator woody species of $\mathrm{Cd}, \mathrm{Pb}$, $\mathrm{Cu}$ and Cr. Braz. J. Plant Physiol. 19, 83-98.

Andrade, M.G., Melo, V.F., Souza, L.C.P., Gabardo, J., Reissmann, C.B. 2009. Heavy metals in soils of a lead mining and metallurgy area. II - forms and plant availability. Braz. J. Soil Sci. 33, 1889-1897

Butcher, D.J. 2009. Phytoremediation of lead in soil: recent applications and future prospects. Appl. Spectrosc. Rev. 44, 123-139.

Chantachon, S., Kruatrachue, M., Pokethitiyook P., Upatham S., Tantanasarit S., Soonthornsarathool, V.2004. Phytoextraction and accumulation of lead from contaminated soil by vetiver grass: Laboratory and simulated field study. Water Air Soil Pollut., 154, 37-55.

Chen, M., Ma, L.Q. 2001. Comparison of three aqua regia digestion methods for twenty Florida soils. Soil Sci. Soc. Am. J., 65, 491499.
Embrapa. 1997. Empresa Brasileira de Pesquisa Agropecuária. Manual for methods of soil analysis, $2^{\text {nd }}$ ed. National Service for Soil Survey and Soil Conservation. Rio de Janeiro, Brazil, 212 p. (in Portuguese).

Finzgar, N., Kos, B., Lestan, D. 2006. Bioavailability and mobility of $\mathrm{Pb}$ after soil treatment with different remediation methods. Plant, Soil and Environm. 52, 2534.

He, X., Taylor, R.W., Shuford, J.W., Tadesse, W., Adriano, D.C. 1991. Comparison of extractants for available sludge-borne metals: a residual study. Water Air Soil Pollut. 57-58, 913-922.

Hseu, Z.Y. 2004. Evaluating heavy metal contents in nine composts using four digestion methods. Bioresour. Technol. 95, 53-59

Intawongse, M., Dean, J.R. 2008. Use of the physiologically-based extraction test to assess the oral bioaccessibility of metals in vegetable plants grown in contaminated soil. Environ. Pollut. 152, 60-72.

Jarvis, M.D., Leung, D.W.M. 2002. Chelated lead transport in Pinus radiata: an ultrastructural study. Environ. Exp. Bot., 48, 21-32.

Kabata-Pendias, A., Pendias, H. 2001. Trace elements in soils and plants. $3^{\text {rd }} \mathrm{ed}$. CRC, Boca Raton Press, 413 p.

Kloke, A., Sauerbeck, D.R., Vetter, H. 1984. The contamination of plants and soils with heavy metals and the transport metals in terrestrial food chains. In: Nriagu, J.O. Changing Metal Cycles and Human Health. Spinger-Verlag, Berlin, pp:113-141. 
Kos, B., Grčman, H., Leštan, D. 2003. Phytoextraction of lead, zinc and cadmium from soil by selected plants. Plant, Soil and Environm. 49, 548-553.

Kosobrukhov, A., Knyazeva, I., Mudrik, V. 2004. Plantago major plants responses to increase content of lead in soil: growth and photosynthesis. Plant Growth Regul. 42, 145-151.

Marques, T.C.L.L.S.M., Moreira, F.M.S., Siqueira, J.O. 2000. Growth and metal concentration of seedlings of wood species in a heavy metal contaminated soil. Braz. Agric. Res. 35, 121-132 (in Portuguese).

Martin, D., Vollenweider, P., Buttler, A., Günthardt-Goerg, M. 2006. Bioindication of heavy metal contamination in vegetable gardens. For. Snow Landsc. Res. 2, 169-180.

Miranda, V.S.; Ribeiro, K.G.; Silva, A.C.; Pereira, R.C.; Pereira, O.G.; Torrado, P.V.; Fernandes, J.S.C.; Oliveira, M.C. 2012. Rehabilitation with forage grasses of an area degraded by urban solid waste deposits. Braz. J. Anim. Sci. 41, 18-23.

Mojiri, A. 2011. The potential of corn (Zea mays) for phytoremediation of soil contaminated with cadmium and lead. J. Biol. \& Environm. Sci. 5, 17-22, 2011.

Nogueira, T.A.R., Oliveira, L.R., Melo, W.J., Fonseca, I.M., Melo, G.M.P., Melo, V.P., Marques, M.O. 2008. Cadmium, chromium, lead and zinc in maize plants and oxisol after nine annual applications of sewage sludge. Braz. J. Soil Sci., 32, 2195-2207 (in Portuguese).

National Research Council. 1996. Nutrient requirements of beef cattle: seventh revised edition. National Academy of Science, Washigton, pp.54-74.
Raskin, I., Smith, R.D., Salt, D.E. 1997. Phytoremediation of metals: using plants to remove pollutants from the environment. Curr. Opin. Biotechnol. 8, 221-226.

Romeiro, S., Lagôa, A.M.M.A., Furlani, P.R., Abreu, C.A., Abreu, M.F., Erismann, N.M. 2006. Lead uptake and tolerance of Ricinus communis L. Braz. J. Plant Physiol. 18, 483489.

São Paulo State Environmental Agency. 2005. Report on standardvalues for soils and groundwater in the São Paulo State. Cetesb, Brazil. Available at: http://www. cetesb.sp.gov.br/Solo/relatorios/tabela valores_2005.pdf (in Portuguese).

Sharma, P.; Dubey, R.S. 2005. Lead toxicity in plants. Braz. J. Plant Physiol., 17, 35-52.

Solhi, S., Solhi, M., Sief, A., Hajabassi, M.A., Shariatmadari, H. 2012. Metal extraction of some native plant species in an contaminated sites of Iran. Int. Res. J. Applied Basic Sci. 3, 568-575.

Szopka, K., Karczewska, A., Jezierski, P., Kabała, C. 2013. Spatial distribution of lead in the surface layers of mountain forest soils, an example from the Karkonosze National Park, Poland. Geoderma. 193, 259-268.

UNITED STATES ENVIRONMENTAL PROTECTION AGENCY. Microwave Assisted Acid Digestion of Sediments, Sludges, Soils and Oils - Method 3052 - SW -846 .

Violante, A., Cozzolino, V., Perelomov, L., Caporale, A.G., Pigna, M. 2010. Mobility and bioavailability of heavy metals and metalloids in soil environments. J. Soil. Sci. Plant Nutr. 10, 268-292. 
Wuana, R.A., Okieimen, F.E. 2011. Heavy metals in contaminated soils: a review of sources, chemistry, risks and best available strategies for remediation. Int. Scholarly Res. Network Ecol. 2011, 1-20.

Zhang, M.K., Liu, Z.Y., Wang, H. 2010. Use of single extraction methods to predict bioavailability of heavy metals in polluted soils to rice. Commun. Soil Sci. Plant Anal., $41,820-831$.
Zhang, Y., Yang, X., Zhang,S., Tian, T., Guo, W., Wang, J. 2013.The influence of humic acids on the accumulation of lead $(\mathrm{Pb})$ and cadmium (Cd) in tobacco leaves grown in different soils. J. Soil Sci. Plant Nutr. 13, 43-43. 